\title{
Chronic pain following physical and emotional trauma:The Station nightclub fire
}

\section{Rachel Egyhazi ${ }^{1}$, Felipe Fregni ${ }^{1,2}{ }^{*}$, Gabriela L. Bravo ${ }^{2}$, Nhi-Ha T. Trinh ${ }^{3}$, Colleen M. Ryan ${ }^{4,5}$ and Jeffrey C. Schneider ${ }^{1,5}$}

${ }^{1}$ Department of Physical Medicine and Rehabilitation, Spaulding Rehabilitation Hospital, Harvard Medical School, Boston, MA, USA

${ }^{2}$ Neuromodulation Center, Spaulding Rehabilitation Hospital, Harvard Medical School, Boston, MA, USA

${ }^{3}$ Depression and Clinical Research Program, Department of Psychiatry, Massachusetts General Hospital, Boston, MA, USA

${ }^{4}$ Department of Surgery, Sumner Redstone Burn Center, Massachusetts General Hospital, Boston, MA, USA

${ }^{5}$ Shriners Hospitals for Children-Boston, Boston, MA, USA

Edited by:

Jia Lu, DSO National Laboratories,

Singapore

Reviewed by:

Karim A. Sarhane, Johns Hopkins University, USA

Pamela Boon Li Pun, Defence

Medical and Environmental Research

Institute, Singapore

*Correspondence:

Felipe Fregni, Department of Physical

Medicine and Rehabilitation,

Neuromodulation Center, Spaulding

Rehabilitation Hospital, 300 1st

Avenue, Charlestown, MA 02129,

USA

e-mail: ffregni@partners.org
Objective: The purpose of this study was to evaluate factors associated with chronic pain in survivors of a large fire, including those with and without burn injury.

Methods:This study employed a survey-based cross-sectional design to evaluate data from survivors of The Station nightclub fire. The primary outcome measure was the presence and severity of pain. Multiple linear regressions with a stepwise approach were used to examine relationships among variables. Variables considered included age, gender, marital status, burn injury, total body surface area, skin graft, pre-morbid employment, time off work, return to same employment, depression (Beck depression inventory, BDI), and post-traumatic stress (impact of event scale - revised).

Results: Of 104 fire survivors, 27\% reported pain at least 28 months after the event. Multiple factors associated with pain were assessed in the univariate analysis but only age $(p=0.012)$, graft $(p=0.009)$, and BDI score $(p<0.001)$ were significantly associated with pain in the multiple regression model.

Discussion: A significant number of fire survivors with and without burn injuries experienced chronic pain. Depth of burn and depression were significantly associated with pain outcome. Pain management should address both physical and emotional risk factors in this population.

Keywords: fire, burn, graft, pain, depression

\section{INTRODUCTION}

Burns are associated with a significant amount of pain during the course of acute care and rehabilitation. Pain has been reported up to 7-12 years after initial injury for a subset of burn patients $(1-3)$. To date, there is limited data regarding the prevalence and characteristics of chronic pain in burn patients, and almost no information regarding pain in fire survivors without physical injury.

Chronic pain is a complex phenomenon involving sensory, physiologic, and cognitive-behavioral components. Chronic pain states are thought to be secondary to molecular and structural reorganization that occur as a result of changes in the sensitivity of the nociceptor peripheral terminal (peripheral sensitization), as well as augmentation of nociceptive synaptic transmission in the dorsal horn of the spinal cord and brain-related pain processing areas such as thalamus, cingulate gyrus, and insula (central sensitization) (4-6). Such mechanisms contribute to altered pain thresholds; pain may be experienced clinically as sensory abnormalities including hyperalgesia, hyperpathia, or allodynia $(5,6)$.

Psychological factors are closely associated with the development and perpetuation of chronic pain states. Emotional experiences can induce neurophysiological changes in important modulating areas of chronic pain, such as the primary motor cortex. It has been recently shown that catastrophizing thoughts are associated with changes in corticospinal excitability in patients with chronic pain (7).

Chronic pain in fire survivors presents a unique challenge to medical practitioners in that we have yet to fully understand the physiological and psychosocial factors that contribute to pain phenomena in this population. Therefore, research that includes long-term follow-up of burn survivors is imperative since medical literature reports that although pain due to burn injury is a welldescribed clinical finding and one of the highest research priorities in the field, it remains undertreated (8). The recognition of factors that contribute to chronic pain can provide a foundation, which medical practitioners can use to guide their treatments.

Experiences of chronic pain appear to be variable among burn survivors, and range from discomfort at the scar site, to focal or generalized neuropathic-like pain and altered sensation $(2,8,9)$. Fire survivors are often subject to significant emotional trauma related to the event itself (10). It is estimated that $20-45 \%$ of burn survivors experience post-traumatic stress disorder (PTSD), 
associated with delusional memories, nightmares, and pain (11). Schneider et al. demonstrated emotional trauma to be more significant than physical injury in predicting long-term impairments in quality of life for survivors of The Station nightclub fire (12).

The Station nightclub of West Warwick, Rhode Island caught fire during an indoor rock concert on February 20, 2003, after pyrotechnic sparks ignited the stage. Of the estimated 462 people in attendance, 100 people died and 230 were injured from burns, smoke inhalation, and trampling (13). One of the deadliest fires in American history, this catastrophic event provides a unique platform to evaluate relationships between pain, physical trauma, and emotional impairment. The objective of this study was to evaluate factors associated with chronic pain in survivors of a large fire.

\section{MATERIALS AND METHODS PARTICIPANTS}

We employed a cross-sectional study design to evaluate data from survivors of The Station nightclub fire. All persons in attendance at The Station nightclub on February 20, 2003 were eligible for inclusion. There were no explicit exclusion criteria. The Partners Human Research Committee approved all procedures utilized in this study.

\section{PROCEDURES: RECRUITMENT AND SURVEY DESIGN}

Subjects were recruited from June 2005 to October 2007. Participants were asked to complete a survey consisting of 130 questions pertaining to demographic, medical, psychological, social, and occupational status. Details regarding the full recruitment process and questionnaire are presented in Schneider et al. (12).

\section{MEASURES}

The primary outcome measure in this dataset analysis was the presence of pain, as assessed by the visual analog scale (VAS). All subjects were asked to assess their level of pain using a horizontal axis scaled from 0 to 10 , corresponding to "no pain," and "worst pain imaginable," respectively.

Independent variables selected from the survey included demographic, medical, and psychosocial characteristics. Demographic characteristics included age, gender, and marital status. Medical characteristics included the presence of burn (yes/no), as well as the severity of burn, measured by percentage of total body surface area (TBSA: $0,1-20, \geq 21 \%$ ), skin grafting (yes/no), and medications used. Psychosocial characteristics included employment and psychological impairment. Specifically, participants were asked if they were employed or in school prior to the fire, duration of time off from work or school as a result of the fire, and whether or not they were able to return to the same occupation after the fire. Degree of psychological impairment was assessed using the Beck depression inventory (BDI) and impact of event scale - revised (IES-R) to evaluate for symptoms of depression and post-traumatic stress, respectively.

\section{DATA ANALYSIS}

Statistical analyses were performed using STATA/IC 12 (StataCorp LP, TX, USA). The first step of modeling involved the selection of covariates. Univariate analysis was performed for each of the predictors using linear regression with only one variable, from which values for the unadjusted $\beta$ coefficients, $p$ values, and 95\% confidence intervals (CIs) were obtained. Next, a stepwise multiple regression with a manual backward elimination approach was used to arrive at the most parsimonious model; all variables with a $p$ value $<0.05$ in the univariate analyses were included initially. During the modeling process, the variable with the highest $p$ value was eliminated from the maximum model, conditioned on the $p$ value being larger than the pre-determined level of 0.05 . After evaluating the fit of the reduced model, the next variable with the highest non-significant $p$ value was removed. This process was continued until no additional variables could be eliminated from the model. In order to avoid excluding non-significant confounders, each of the excluded variables were examined by adding them individually to the model; confounding was defined by changes of $\geq 10 \%$ in the $\beta$ coefficient. Any variable identified as an important confounder or clinically relevant was forced into the final model.

As a final consideration, an interaction term was constructed for each paired combination of significant variables from the final multiple regression model. This identified whether or not the simultaneous influence of the two variables on the remaining variable was additive. An additional regression analysis was performed using an interaction term created from all of the three significant predictors to evaluate higher order interactions.

\section{RESULTS}

\section{CHARACTERISTICS OF THE STUDY SAMPLE}

Of the estimated 462 people in attendance at The Station nightclub at the time of the fire, 362 people survived $(12,13)$. The recruitment process identified 144 eligible participants, of which 104 people completed the survey.

Demographic, medical, and psychosocial characteristics of respondents are presented in Table 1 . At the time of the fire, survivors ranged in age from 19 to 57 years; the mean age was 32 and the mode was 39 years. Almost one-half (47\%) experienced a burn injury, of which the most common size was $\leq 20 \%$ TBSA (59\%), followed by $21-40 \%$ TBSA (27\%). The most common areas burned included the head (75\%) and upper extremities (65\%). Twenty-nine percent of people who sustained a burn injury received a graft. Nearly all participants were found to exhibit some degree of depressive symptoms, with a minority of survivors $(22 \%)$ reporting moderate to severe symptoms. Nearly one-half (49\%) of survivors were identified as having moderate to severe symptoms of post-traumatic stress. Survey of employment status demonstrated that $34 \%$ of survivors returned to full-time work after the fire, with $80 \%$ returning to their pre-morbid occupation. Time off from work was variable, ranging from a leave of absence of 1 week $(30 \%)$ to more than 1 year $(16 \%)$.

Pain characteristics of the study sample are demonstrated in Table 2 and Figure 1. Of the 104 participants surveyed, 27 people (27\%) reported pain (VAS from 1 to 10 ); the average pain score was $3.1 \pm 2.6$ (mean $\pm \mathrm{SD}$ ). Pain among subgroups of patients with varying burn characteristics was further analyzed. Of those 14 survivors who underwent grafting due to burn, $71 \%$ reported pain at the time of the study. This was nearly double the percentage of burn survivors without grafts who experienced pain $(37 \%)$. Of those grafted patients with pain, the mean VAS pain score was $3.4 \pm 2.9$, with an average VAS score of $2.4 \pm 2.9$ for all grafted 
Table 1 | Characteristics of study sample.

\begin{tabular}{|c|c|c|}
\hline Category & Characteristics & $\begin{array}{l}\text { Number (\%), } \\
n=104^{\mathrm{a}}\end{array}$ \\
\hline \multirow[t]{5}{*}{ Demographic } & Gender & \\
\hline & Female & $40(38 \%)$ \\
\hline & Age at time of fire, mean years (SD) & $32.4(7.2)$ \\
\hline & Marital status & \\
\hline & Married or long-term partner & $94(90 \%)$ \\
\hline \multirow[t]{6}{*}{ Medical } & Survivors with burn injury & $49(47 \%)$ \\
\hline & Total body surface area burned & \\
\hline & $\leq 20 \%$ & $29(59 \%, n=49)$ \\
\hline & $21-40 \%$ & $13(27 \%, n=49)$ \\
\hline & $>40 \%$ & $7(14 \%, n=49)$ \\
\hline & Graft & $14(29 \%, n=49)$ \\
\hline \multirow[t]{10}{*}{ Psychiatric } & Depressive symptoms (BDI) $)^{\mathrm{b}}$ & \\
\hline & Minimal & $66(63 \%)$ \\
\hline & Mild & $9(9 \%)$ \\
\hline & Moderate & $14(13 \%)$ \\
\hline & Severe & $9(9 \%)$ \\
\hline & $\begin{array}{l}\text { Post-traumatic stress symptoms } \\
(\text { IES-R) }\end{array}$ & \\
\hline & Subclinical & $22(21 \%)$ \\
\hline & Mild & $29(28 \%)$ \\
\hline & Moderate & $23(22 \%)$ \\
\hline & Severe & $28(27 \%)$ \\
\hline \multirow[t]{18}{*}{ Employment } & Pre-morbid employment & \\
\hline & Full-time & $83(80 \%)$ \\
\hline & Part-time & $9(9 \%)$ \\
\hline & Student & $5(5 \%)$ \\
\hline & Unemployed & $3(3 \%)$ \\
\hline & Not specified & $4(4 \%)$ \\
\hline & Employment after fire & \\
\hline & Full-time & $35(34 \%)$ \\
\hline & Part-time & $9(9 \%)$ \\
\hline & Unemployed & $12(12 \%)$ \\
\hline & Not specified & $48(46 \%)$ \\
\hline & Return to same job post-fire & $83(80 \%)$ \\
\hline & Time off work & \\
\hline & $1-7$ days & $31(30 \%)$ \\
\hline & $1-3$ weeks & $17(16 \%)$ \\
\hline & $1-5$ months & $18(17 \%)$ \\
\hline & $6-12$ months & $12(12 \%)$ \\
\hline & $>1$ year & $17(16 \%)$ \\
\hline
\end{tabular}

${ }^{a}$ Percentages are relative to total number of study participants $(n=104)$, unless otherwise indicated.

${ }^{b} B D I$, Beck depression inventory.

CIES-R, impact event scale - revised.

survivors. Non-grafted burn patients with pain were found to have a mean VAS pain score of $3.0 \pm 2.5$, with an average VAS score of $1.1 \pm 2.1$ for this group overall. Only 4 of 50 participants without burn reported pain, with an average VAS score of $3.0 \pm 2.8$; of these, 1 patient was noted to have sustained a crush injury. The mean VAS pain score for all survivors without burn was $0.2 \pm 1.1$.
Table 2 | Pain characteristics of study sample.

\begin{tabular}{ll}
\hline Characteristic & Number (\%) \\
\hline Fire survivors & 104 \\
Unknown level of pain & 3 \\
Pain, VAS 1-10 & $27(27 \%)$ \\
No pain, VAS 0 & $74(73 \%)$ \\
Mean VAS, all fire survivors with pain (SD) & $3.1(2.6)$ \\
Burn with graft & $14(29 \%)$ \\
Pain, VAS 1-10 & $10(71 \%)$ \\
No pain, VAS 0 & $4(29 \%)$ \\
Mean VAS, grafted survivors with pain (SD) & $3.4(2.9)$ \\
Mean VAS, all grafted survivors (SD) & $2.4(2.9)$ \\
Burn without graft & $35(71 \%)$ \\
Pain, VAS 1-10 & $13(37 \%)$ \\
No pain, VAS 0 & $21(60 \%)$ \\
No response & \\
Mean VAS, non-grafted survivors with pain (SD) & $1(3 \%)$ \\
Mean VAS, all non-grafted survivors (SD) & $3.0(2.5)$ \\
No burn & $1.1(2.1)$ \\
Pain, VAS 1-10 & $50(51 \%)$ \\
No pain, VAS 0 & $4(8 \%)$ \\
No response & $28(56 \%)$ \\
Mean VAS, non-burn survivors with pain (SD) & $18(36 \%)$ \\
Mean VAS, all non-burn survivors (SD) & $3.0(2.8)$ \\
\hline
\end{tabular}

${ }^{a}$ Considered equivalent to VAS O for purposes of mean calculation.

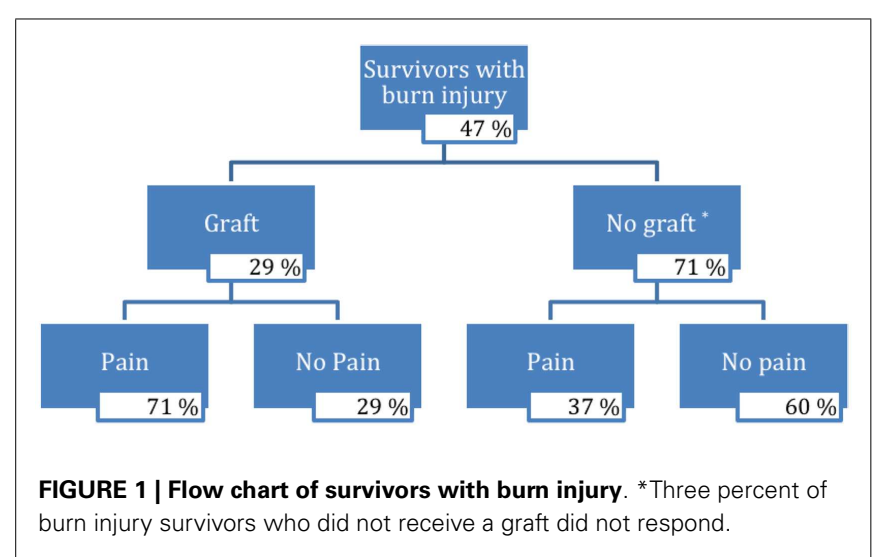

\section{UNIVARIATE AND MULTIVARIATE ANALYSIS}

The results of the univariate analysis are presented in Table 3. The variables that were significantly associated with VAS pain score included: age $(p=0.009)$, burn injury $(p=0.012)$, graft $(p=0.006)$, time off work $(p=0.001)$, return to same employment $(p<0.001)$, BDI score $(p<0.001)$, and IES-R score $(p<0.001)$. Marital status $(p=0.920)$, gender (female, $p=0.655)$, pre-morbid employment $(p=0.131)$, and TBSA $(p=0.577)$ were not found to be significant predictors. All significant variables were included for consideration in the model. Although not itself 
Table 3 | Univariate analysis of pain outcome with multiple covariates.

\begin{tabular}{lrcr}
\hline Predictor & $\begin{array}{l}\boldsymbol{\beta} \text { coeffi- } \\
\text { cient }\end{array}$ & $\mathbf{9 5 \%} \mathbf{C l}$ & $\begin{array}{l}\text { Unadjusted } \\
\boldsymbol{p} \text { value }^{\mathbf{a}}\end{array}$ \\
\hline Age & 0.08 & $0.02-0.15$ & 0.009 \\
Female & -0.22 & -1.17 to 0.74 & 0.655 \\
Marital status & 0.02 & -0.34 to 0.38 & 0.920 \\
Burn & 1.17 & $0.27-2.07$ & 0.012 \\
Total body surface area \% & -0.01 & -0.04 to 0.02 & 0.577 \\
Graft & -1.67 & -2.84 to -0.49 & 0.006 \\
BDI & 0.09 & $0.06-0.13$ & $<0.001$ \\
IES-R & 0.04 & $0.02-0.05$ & $<0.001$ \\
Pre-morbid employment & 0.54 & -0.16 to 1.24 & 0.131 \\
Return to same employment & 2.08 & $1.06-3.10$ & $<0.001$ \\
Time off from work & 0.51 & $0.20-0.82$ & 0.001 \\
\hline
\end{tabular}

a Statistically significant defined as $p \leq 0.05$.

$B D I$, Beck depression inventory.

IES-R, impact event scale - revised.

significant, gender was forced into the model due to its previously reported association with psychiatric outcomes in burn patients (14-16).

Table 4 displays the results of the stepwise multiple regression. Amongst the eight variables identified by the univariate analyses, five variables were eliminated through the model building process. The final model (Model 5) yielded the following significant predictors: age $(p=0.012)$, graft $(p=0.009)$, and BDI $(p<0.001)$. Similar data variability of $36-41 \%$ was seen between models; the final model produced an $R^{2}$ of 0.38 , indicative of its ability to predict $38 \%$ of the variability amongst pain scores. No confounders were identified for the three variables that remained significant in the final model.

In order to test if there was a synergistic effect between predictors, paired and higher order interaction terms were forced into the model. Table 5 shows the results of the paired interactions for age and BDI, age and graft, and BDI and graft. A trend toward significance was noted for the interaction between age and depression $(p=0.052)$, as well as age and graft $(p=0.072)$. Similarly, there was found to be a trend toward significance of $p=0.057$ for the three-way interaction between age, graft, and depression. Only the interaction between graft and depression was shown to be highly significant ( $p=0.003$ ) relative to VAS pain score.

\section{DISCUSSION}

This survey of 104 survivors of The Station nightclub fire provides a unique opportunity to study chronic pain in individuals exposed to the same traumatic event. The findings suggest that pain in these subjects may be related to age, graft, and depressive symptoms. In addition, there was observed to be an interaction between graft and BDI score. The final model was able to explain $38 \%$ of the variability among pain scores.

\section{BURN INJURY AND PAIN}

This study found that fire survivors who sustained physical burn injury were more likely to report pain 28-56 months after the event, compared to those without burn. Burn size, as measured by total body surface area, was not a significant predictor of pain. Survivors who received grafts reported higher VAS pain scores than burn patients without grafts.

One possible explanation for the relationship between pain and grafting may be related to the physiology of the burn injury itself. The size of a burn alone is an unreliable indicator of clinical burn severity, since it is not uncommon for a given injury to contain regions of different depths. The requirement for skin grafting, however, may more accurately approximate deeper or more complex injury (17-19). The deeper the burn, the more progressive the structural damage to the dermis and underlying tissues. Deeper injuries heal more slowly, are more difficult to treat, and are more likely to be associated with local and systemic complications (20).

In deep burn injuries, all types of nociceptor afferents are affected, including both large-diameter, small myelinated, and unmyelinated C-fibers $(3,8)$. In grafted tissue, there may be preferential loss of large fibers (3), with deeper C-fibers capable of responding to pain to varying degrees (21). Damage to tissue surrounding a burn, either due to natural wound progression or as a consequence of medical intervention, may also result in peripheral nerve damage $(3,22)$. As neuronal cell regeneration occurs, an altered chemical milieu further contributes to abnormal excitability $(3,21)$.

Persistent, abnormal stimulus from the periphery contributes to changes in the central processing of pain and sensation $(5,6)$. These alterations may be transient in nature; Volz et al. recently demonstrated that, when one hand is exposed to increased sensory stimulation, pain threshold increases on the side of stimulation and decreases in the contralateral, unprovoked hand (23). Changes in peripheral and central sensory processing may lead to cortical reorganization and structural changes $(3,8,21,24)$, factors which have been linked to the development of chronic pain (4-6). Transcranial magnetic stimulation studies have shown subjects with neuropathic pain to have defective inhibition of the primary motor cortex $(25,26)$.

Studies of burn survivors have suggested that the co-occurrence of painful sensations and impaired sensibility are not uncommon, specially after deep burns and grafted injuries $(1,3,8,27)$. In one study of 121 burn survivors, patients with deep burns requiring skin grafts demonstrated decreased sensory perception by displaying significantly higher thresholds for pressure, discriminative, thermal, and pain modalities compared to individuals with superficial injury. Interestingly, sensory abnormalities were also seen in uninjured areas (8). Earlier, qualitative studies have noted similar findings. In a retrospective review of 60 grafted burn survivors, $97 \%$ of patients exhibited markedly diminished or absent response to various types of stimuli. Depth of burn was the best predictor of altered sensation, and non-grafted skin areas frequently recovered normal sensation (27). In multiple investigations, patients frequently described subjective, neuropathiclike symptoms of pain, paresthesias, and pruritus up to 12 years post-injury (1-3, 9, 21, 27, 28).

More recent studies have begun to elucidate the central neuropathic mechanisms that may contribute to chronic pain after burn. In one animal model, unilateral partial-thickness burn injury was noted to produce persistent bilateral allodynia associated with neuronal hyperexcitability and microglial activation in the spinal cord 
Table 4 | Stepwise multiple regression analysis examining predictors of pain.

\begin{tabular}{|c|c|c|c|c|c|c|c|c|c|c|c|c|c|c|c|}
\hline \multirow{2}{*}{$\begin{array}{l}\text { Significant } \\
\text { predictors }\end{array}$} & \multicolumn{3}{|c|}{ Model 1} & \multicolumn{3}{|c|}{ Model 2} & \multicolumn{3}{|c|}{ Model 3} & \multicolumn{3}{|c|}{ Model 4} & \multicolumn{3}{|c|}{ Model 5} \\
\hline & $\begin{array}{l}\beta \text { coeffi- } \\
\text { cient }\end{array}$ & $95 \% \mathrm{Cl}$ & $p$ Value $^{\mathrm{a}}$ & $\begin{array}{l}\beta \text { coeffi- } \\
\text { cient }\end{array}$ & $95 \% \mathrm{Cl}$ & $p$ Value $^{\mathrm{a}}$ & $\begin{array}{l}\beta \text { coeffi- } \\
\text { cient }\end{array}$ & $95 \% \mathrm{Cl}$ & $p$ Value $^{\mathrm{a}}$ & $\begin{array}{l}\beta \text { coeffi- } \\
\text { cient }\end{array}$ & $95 \% \mathrm{Cl}$ & $p$ Value $^{\mathrm{a}}$ & $\begin{array}{l}\beta \text { coeffi- } \\
\text { cient }\end{array}$ & $95 \% \mathrm{Cl}$ & $p$ Value $^{a}$ \\
\hline Age & 0.09 & $\begin{array}{l}0.02- \\
0.16\end{array}$ & 0.016 & 0.09 & $\begin{array}{l}0.02- \\
0.16\end{array}$ & 0.014 & 0.07 & $\begin{array}{l}0.01- \\
0.14\end{array}$ & 0.023 & 0.08 & $\begin{array}{l}0.01- \\
0.14\end{array}$ & 0.020 & 0.08 & $\begin{array}{l}0.02- \\
0.14\end{array}$ & 0.012 \\
\hline Female & -0.62 & $\begin{array}{l}-1.52 \text { to } \\
0.28\end{array}$ & 0.174 & -0.60 & $\begin{array}{l}-1.49 \text { to } \\
0.30\end{array}$ & 0.187 & -0.66 & $\begin{array}{l}-1.49 \text { to } \\
0.18\end{array}$ & 0.123 & -0.61 & $\begin{array}{l}-1.43 \text { to } \\
0.22\end{array}$ & 0.149 & -0.57 & $\begin{array}{l}-1.39 \text { to } \\
0.26\end{array}$ & 0.173 \\
\hline Burn & 0.41 & $\begin{array}{l}-0.88 \text { to } \\
1.70\end{array}$ & 0.527 & & & & & & & & & & & & \\
\hline Graft & -1.54 & $\begin{array}{l}-2.97 \text { to } \\
-0.10\end{array}$ & 0.037 & -1.57 & $\begin{array}{l}-3.00 \text { to } \\
-0.15\end{array}$ & 0.031 & -1.33 & $\begin{array}{l}-2.51 \text { to } \\
-0.15\end{array}$ & 0.028 & -1.21 & $\begin{array}{l}-2.36 \text { to } \\
-0.06\end{array}$ & 0.039 & -1.43 & $\begin{array}{l}-2.49 \text { to } \\
-0.37\end{array}$ & 0.009 \\
\hline BDI & 0.03 & $\begin{array}{l}-0.04 \text { to } \\
0.10\end{array}$ & 0.439 & 0.03 & $\begin{array}{l}-0.04 \text { to } \\
0.10\end{array}$ & 0.445 & 0.05 & $\begin{array}{l}-0.01 \text { to } \\
0.12\end{array}$ & 0.093 & 0.08 & $\begin{array}{l}0.04- \\
0.12\end{array}$ & $<0.001$ & 0.08 & $\begin{array}{l}0.04- \\
0.12\end{array}$ & $<0.001$ \\
\hline IES-R & 0.02 & $\begin{array}{l}-0.01 \text { to } \\
0.05\end{array}$ & 0.271 & 0.02 & $\begin{array}{l}-0.01 \text { to } \\
0.05\end{array}$ & 0.252 & 0.01 & $\begin{array}{l}-0.02 \text { to } \\
0.04\end{array}$ & 0.379 & & & & & & \\
\hline Time off work & -0.19 & $\begin{array}{l}-0.76 \text { to } \\
0.38\end{array}$ & 0.511 & -0.07 & $\begin{array}{l}-0.51 \text { to } \\
0.36\end{array}$ & 0.743 & & & & & & & & & \\
\hline $\begin{array}{l}\text { Return to same } \\
\text { employment }\end{array}$ & $\begin{array}{c}0.80 \\
\text { Model } 1\end{array}$ & $\begin{array}{l}-0.82 \text { to } \\
2.42 \\
\left.R^{2}=0.37\right)\end{array}$ & 0.329 & $\begin{array}{c}0.62 \\
\text { Model } 2\end{array}$ & $\begin{array}{l}-0.89 \text { to } \\
2.13 \\
\left.R^{2}=0.36\right)\end{array}$ & 0.417 & $\begin{array}{c}0.56 \\
\text { Model } 3\end{array}$ & $\begin{array}{l}-0.65 \text { to } \\
1.78 \\
\left.R^{2}=0.41\right)\end{array}$ & 0.359 & $\begin{array}{c}0.47 \\
\text { Model } 4\end{array}$ & $\begin{array}{l}-0.73 \text { to } \\
1.66 \\
\left.R^{2}=0.40\right)\end{array}$ & 0.438 & Model 5 & $\left.R^{2}=0.38\right)$ & \\
\hline
\end{tabular}

${ }^{a}$ Statistically significant defined as $p \leq 0.05$.

$B D I$, Beck depression inventory.

IES-R, impact event scale - revised. 
Table 5 | Interaction analysis between pairs of significant predictors of pain.

\begin{tabular}{|c|c|c|c|}
\hline Significant predictors ${ }^{a}$ & $\begin{array}{l}\beta \text { coeffi- } \\
\text { cient }\end{array}$ & $95 \% \mathrm{Cl}$ & $p$ Value $^{\text {b }}$ \\
\hline \multicolumn{4}{|l|}{ INTERACTION 1. AGE AND BDIC } \\
\hline Age & 0.01 & -0.08 to 0.10 & 0.860 \\
\hline Female & -0.44 & -1.26 to 0.37 & 0.281 \\
\hline Graft & -1.27 & -2.32 to -0.22 & 0.018 \\
\hline BDI & -0.11 & -0.31 to 0.08 & 0.261 \\
\hline Interaction term (age and $\mathrm{BDI}^{\mathrm{C}}$ ) & 0.01 & $0.00-0.01$ & 0.052 \\
\hline \multicolumn{4}{|l|}{ Interaction $1\left(R^{2}=0.41\right)$} \\
\hline \multicolumn{4}{|c|}{ INTERACTION 2. AGE AND GRAFT } \\
\hline Age & 0.21 & $0.05-0.37$ & 0.009 \\
\hline Female & -0.56 & -1.37 to -0.25 & 0.175 \\
\hline Graft & 3.31 & -1.97 to 8.58 & 0.215 \\
\hline BDI & 0.07 & $0.04-0.11$ & $<0.001$ \\
\hline Interaction term (age and graft) & -0.15 & -0.32 to 0.01 & 0.072 \\
\hline \multicolumn{4}{|l|}{ Interaction $2\left(R^{2}=0.41\right)$} \\
\hline \multicolumn{4}{|c|}{ INTERACTION 3. BDI' AND GRAFT } \\
\hline Age & 0.07 & $0.01-0.12$ & 0.028 \\
\hline Female & -0.37 & -1.16 to 0.42 & 0.350 \\
\hline Graft & 0.39 & -1.17 to 1.95 & 0.619 \\
\hline BDI & 0.19 & $0.11-0.27$ & $<0.001$ \\
\hline Interaction term (BDI ${ }^{\mathrm{C}}$ and graft) & -0.13 & -0.22 to -0.04 & 0.003 \\
\hline Interaction $3\left(R^{2}=0.45\right)$ & & & \\
\hline
\end{tabular}

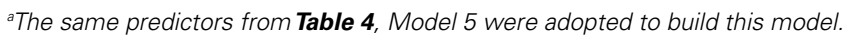

${ }^{b}$ Statistically significant defined as $p \leq 0.05$.

${ }^{c} B D I$, Beck depression inventory.

dorsal horn (24). Clinical studies have provided similar evidence of maladaptive neuroplasticity. Burn patients receiving transcranial direct current stimulation have been shown to demonstrate an overall decrease in cortical excitability characterized by an increase in intracortical inhibition and a decrease in intracortical facilitation and motor evoked potentials (29). Future research is needed to help correlate observed chronic pain phenomenon in fire survivors with pathophysiological changes.

\section{AGE AND PAIN}

Age was found to be a significant predictor of pain among fire survivors. Despite the relatively young age range of the cohort, older age corresponded to higher pain scores. This is one of the first studies of pain in fire survivors to report such an association. In part, this may be due to the fact that many previous studies of pain and cutaneous sensibility following burn have been qualitative in nature and may not have had adequate statistical power to detect an age-related effect.

Several physical factors may predispose older individuals to develop a greater degree of pain following burn injury. Dermatologic changes that occur with aging include decreased cutaneous perfusion, alterations in skin strata thickness, changes in collagen and elastin distribution and quality, and reduced lipid content (30, 31). Age-related changes in proliferative response and inflammatory mediators may result in increased susceptibility to injury as well as a decline in wound repair $(32,33)$. In particular, older adults tend to suffer more severe burns at lower temperatures and in less time than their younger adult counterparts $(33,34)$.

Experimental data on age-related changes in pain perception have produced varied results. Some studies have shown that older individuals have enhanced pain sensitivity related to activation of pressure nociceptors in deep tissue (35-38). Other data have suggested age-related deterioration of endogenous pain inhibitory systems $(39,40)$. More recently, a comprehensive multimodal sensory approach was used to evaluate age-related pain sensitivity in a group of 40 individuals; results demonstrated a markedly increased temporal summation of heat pain in elderly individuals $(38,41)$. Temporal summation has been shown to be a centrally mediated process, thought to play an important role in pain amplification and the development of chronic pain conditions $(38,42,43)$.

While physical factors and differences in pain perception are certainly important factors in chronic pain development with age, their relevance is less apparent for this study sample. At the time of the fire, survivors ranged in age from 19 to 57 years, representing a relatively youthful population. The study design also attempted to control the variable age for TBSA or the presence of graft; thus, it is less likely that burn injury itself would be the mechanism to explain a greater degree of pain in older individuals. Additional investigations are needed to evaluate factors that contribute to age-related chronic pain in fire survivors with and without physical injury.

\section{PSYCHOLOGICAL STRESSORS AND PAIN}

This study demonstrated an association between depressive symptoms and pain scores among survivors of a large fire. This association was more pronounced for individuals who underwent grafting. Although many survivors reported symptoms of posttraumatic stress, such symptoms were not found to be a significant predictor of pain when controlled for other variables.

Chronic pain is a complex human experience that encompasses physical, psychological, and sociobehavioral components. It is well-recognized that individuals with chronic pain have an increased incidence of anxiety and mood disorders (44-47). Although existing data are scarce regarding emotional disturbance in fire survivors without physical injury, it is not uncommon for burn survivors to report psychological symptoms. Studies have demonstrated prevalence rates of $7-46 \%$ for depression and 9 $45 \%$ for PTSD up to 1 year following burn injury $(11,48)$. In a retrospective study of 492 burn patients, symptom severity was significantly increased in those individuals who reported persistent pain up to 11 years after their injury. These patients were also found to recall higher levels of pain at rest, with dressing changes, and with physical activity during their acute care stay (48).

Recent experimental models may offer some explanation for the association between emotional trauma and chronic pain phenomena. Functional MRI has shown that, following depressed mood induction, brain responses to noxious thermal stimuli are increased in multiple areas including the inferior frontal gyrus and amygdala (49). Other studies have demonstrated a significant correlation between catastrophizing thoughts and changes in motor cortex excitability (7). In patients with burn injury, catastrophizing thoughts and the development of mood disturbance may result in dysregulation of the neural circuitry underlying emotion 
regulation; this could alter central pain processing and result in an amplification of pain perception $(49,50)$.

Although this study suggests a relationship between depression and chronic pain in fire survivors, the directionality of this relationship remains unclear. While not all survivors suffered burn injury, future investigation is needed to determine whether trauma-induced depression leads to pain amplification, or burn-related neuropathic pain leads to depressive symptoms.

\section{STUDY LIMITATIONS AND FUTURE CONSIDERATIONS}

A few limitations to the study are worth noting. Since only 104 of the estimated 330 survivors completed the survey, there is potential for a selection bias. There is also a risk of a reporting bias with the use of a self-reported questionnaire. Since subjects completed the questionnaire at different points in time, a comparison of long-term outcomes becomes more challenging. Furthermore, the cross-sectional study design precludes the evaluation of longitudinal change and the determination of causal relationships. Additional limitations in study design are presented in Schneider et al. (12).

While this study considered chronic pain as a function of VAS score, it may be more instructive to consider additional pain parameters, including location and sensory abnormalities. Other patient factors including pre-morbid pain and psychiatric characteristics, as well as pharmacologic intervention might also be considered. Since this was a self-reported questionnaire, duration and frequency of medication could not be appropriately collected.

This study highlights the importance of long-term follow-up of fire survivors, including those without burn injury. Although factors such as age and graft are non-modifiable, it is important to take into account that prompt intervention of depressive symptoms and post-traumatic stress could modify pain perception in this patient cohort. Understanding factors that contribute to chronic pain will help medical practitioners better care for their patients in the future.

\section{ACKNOWLEDGMENTS}

Funding sources: the content of this manuscript was developed under a grant from the Department of Education, NIDRR grant number H133A120034. However, this content does not necessarily represent the policy of the Department of Education, and endorsement by the Federal Government should not be assumed.

\section{REFERENCES}

1. Choiniere M, Melzack R, Papillon J. Pain and paresthesia in patients with healed burns: an exploratory study. J Pain Symptom Manage (1991) 6:437-44. doi:10.1016/0885-3924(91)90043-4

2. Malenfant A, Forget R, Papillon J, Amsel R, Frigon JY, Choiniere M. Prevalence and characteristics of chronic sensory problems in burn patients. Pain (1996) 67:493-500. doi:10.1016/0304-3959(96)03154-5

3. Summer GJ, Puntillo KA, Miaskowski C, Green PG, Levine JD. Burn injury pain: the continuing challenge. J Pain (2007) 8:533-48. doi:10.1016/j.jpain.2007. 02.426

4. Vadivelu N, Sinatra R. Recent advances in elucidating pain mechanisms. Curr Opin Anaesthesiol (2005) 18:540-7. doi:10.1097/01.aco.0000183109.27297.75

5. Brenner GJ. Neurophysiologic basis of pain. 3rd ed. In: Ballantyne JC, editor. The Massachusetts General Hospital Handbook of Pain Management. Philadelphia, PA: Lippincott Williams Wilkins (2006). p. 3-18.

6. Decosterd I, Woolf CJ. Pain mechanisms and their importance in clinical practice and research. 3rd ed. In: Ballantyne JC, editor. The Massachusetts General
Hospital Handbook of Pain Management. Philadelphia, PA: Lippincott Williams Wilkins (2006). p. 19-27.

7. Volz MS, Medeiros LF, Tarragô MDG, Vidor LP, Dall'Agnol L, Deitos A et al. The relationship between cortical excitability and pain catastrophizing in myofascial pain. J Pain (2013) 14:1140-7. doi:10.1016/j.jpain.2013.04.013

8. Malenfant A, Forget R, Amsel R, Papillon J, Frigon JY, Choiniere M. Tactile, thermal and pain sensibility in burned patients with and without chronic pain and paresthesia problems. Pain (1998) 77:241-51. doi:10.1016/S0304-3959(98) 00096-7

9. Schneider JC, Harris NL, El Shami A, Sheridan RL, Schulz JT III, Bilodeau ML, et al. A descriptive review of neuropathic-like pain after burn injury. J Burn Care Res (2006) 27:524-8. doi:10.1097/01.BCR.0000226019.76946.5D

10. Green BL, Grace MC, Lindy JD, Titchener JL, Lindy JG. Levels of functional impairment following a civilian disaster: the Beverly Hills supper club fire. JConsult Clin Psychol (1983) 51:573-80. doi:10.1037/0022-006X.51.4.573

11. Esselman PC, Thombs BD, Magyar-Russell G, Fauerbach JA. Burn rehabilitation: state of the science. Am J Phys Med Rehabil (2006) 85:383-413. doi:10.1097/01.phm.0000202095.51037.a3

12. Schneider JC, Trinh NH, Selleck E, Fregni F, Salles SS, Ryan CM, et al. The longterm impact of physical and emotional trauma: the station nightclub fire. PLoS One (2012) 7:e47339. doi:10.1371/journal.pone.0047339

13. Parker PE. Tally of a tragedy: 462 were in the station on night of fire. Providence $J$ (2007) A.1.

14. Difede J, Jaffe AB, Musngi G, Perry S, Yurt R. Determinants of pain expression in hospitalized burn patients. Pain (1997) 72:245-51. doi:10.1016/S0304-3959(97) 00045-6

15. Wiechman SA, Ptacek JT, Patterson DR, Gibran NS, Engrav LE, Heimbach DM. Rates, trends, and severity of depression after burn injuries. J Burn Care Rehabil (2001) 22:417-24. doi:10.1097/00004630-200111000-00012

16. Gould NF, McKibben JB, Hall R, Corry NH, Amoyal NA, Mason ST, et al. Peritraumatic heart rate and posttraumatic stress disorder in patients with severe burns. J Clin Psychiatry (2011) 72:539-47. doi:10.4088/JCP.09m05405blu

17. Jackson DM. The diagnosis of the depth of burning. Br J Surg (1953) 40:588-96. doi:10.1002/bjs.18004016413

18. Jaskille AD, Ramella-Roman JC, Shupp JW, Jordan MH, Jeng JC. Critical review of burn depth assessment techniques: part II. Review of laser Doppler technology. J Burn Care Res (2010) 31:151-7. doi:10.1097/BCR.0b013e3181c7ed60

19. Darwish A. Indications of Skin Graft. In: Spear M, editor. Skin Grafts Indications, Applications and Current Research. InTech (2011). doi:10. 5772/21916. Available from: http://www.intechopen.com/books/skin-graftsindications-applications-and-current-research/indications-of-skin-graft

20. Tiwari VK. Burn wound: how it differs from other wounds? Indian J Plast Surg (2012) 45:364-73. doi:10.4103/0970-0358.101319

21. Zachariah JR, Rao AL, Prabha R, Gupta AK, Paul MK, Lamba S. Post burn pruritus - a review of current treatment options. Burns (2012) 38:621-9. doi:10.1016/j.burns.2011.12.003

22. Lee MY, Liu G, Kowlowitz V, Hwang JH, Lee JH, Choi KH, et al. Causative factors affecting peripheral neuropathy in burn patients. Burns (2009) 35:412-6. doi:10.1016/j.burns.2008.08.009

23. Volz MS, Suarez-Contreras V, Mendonca ME, Pinheiro FS, Merabet LB, Fregni F. Effects of sensory behavioral tasks on pain threshold and cortical excitability. PLoS One (2013) 8:e52968. doi:10.1371/journal.pone.0052968

24. Chang YW, Tan A, Saab C, Waxman S. Unilateral focal burn injury is followed by long-lasting bilateral allodynia and neuronal hyperexcitability in spinal cord dorsal horn. J Pain (2010) 11:119-30. doi:10.1016/j.jpain.2009.06.009

25. Lefaucheur JP, Drouot X, Menard-Lefaucheur I, Keravel Y, Nguyen JP. Motor cortex rTMS restores defective intracortical inhibition in chronic neuropathic pain. Neurology (2006) 67:1568-74. doi:10.1212/01.wnl. $0000242731.10074 .3 \mathrm{c}$

26. Schwenkreis P, Scherens A, Ronnau AK, Hoffken O, Tegenthoff M, Maier C. Cortical disinhibition occurs in chronic neuropathic, but not in chronic nociceptive pain. BMC Neurosci (2010) 11:73. doi:10.1186/1471-2202-11-73

27. Ward RS, Saffle JR, Schnebly WA, Hayes-Lundy C, Reddy R. Sensory loss over grafted areas in patients with burns. J Burn Care Rehabil (1989) 10:536-8. doi:10.1097/00004630-198911000-00015

28. Carrougher GJ, Martinez EM, McMullen KS, Fauerbach JA, Holavanahalli RK, Herndon DN, et al. Pruritus in adult burn survivors: postburn prevalence and risk factors associated with increased intensity. J Burn Care Res (2013) 34:94-101. doi:10.1097/BCR.0b013e3182644c25 
29. Portilla AS, Bravo GL, Miraval FK, Villamar MF, Schneider JC, Ryan CM, et al. A feasibility study assessing cortical plasticity in chronic neuropathic pain following burn injury. J Burn Care Res (2013) 34:e48-52. doi:10.1097/BCR. 0b013e3182700675

30. Waller JM, Maibach HI. Age and skin structure and function, a quantitative approach (I): blood flow, $\mathrm{pH}$, thickness, and ultrasound echogenicity. Skin Res Technol (2005) 11:221-35. doi:10.1111/j.0909-725X.2005.00151.x

31. Waller JM, Maibach HI. Age and skin structure and function, a quantitative approach (II): protein, glycosaminoglycan, water, and lipid content and structure. Skin Res Technol (2006) 12:145-54. doi:10.1111/j.0909-752X.2006.00146.x

32. Swift ME, Burns AL, Gray KL, Dipietro LA. Age-related alterations in the inflammatory response to dermal injury. J Invest Dermatol (2001) 117:1027-35. doi:10.1046/j.0022-202x.2001.01539.x

33. Church D, Elsayed S, Reid O, Winston B, Lindsay R. Burn wound infections. Clin Microbiol Rev (2006) 19:403-34. doi:10.1128/CMR.19.2.403-434.2006

34. Rai B, Anand S. Current management of maxillofacial burn. Internet J Dent Sci (2006) 5:1.

35. Woodrow KM, Friedman GD, Siegelaub AB, Collen MF. Pain tolerance: differences according to age, sex and race. Psychosom Med (1972) 34:548-56. doi:10.1097/00006842-197211000-00007

36. Edwards RR, Fillingim RB. Age-associated differences in responses to noxious stimuli. J Gerontol A Biol Sci Med Sci (2001) 56:M180-5. doi:10.1093/gerona/ 56.3.M180

37. Pickering G, Jourdan D, Eschalier A, Dubray C. Impact of age, gender and cognitive functioning on pain perception. Gerontology (2002) 48:112-8. doi:10.1159/ 000048937

38. Lautenbacher S, Kunz M, Strate P, Nielsen J, Arendt-Nielsen L. Age effects on pain thresholds, temporal summation and spatial summation of heat and pressure pain. Pain (2005) 115:410-8. doi:10.1016/j.pain.2005.03.025

39. Washington LL, Gibson SJ, Helme RD. Age-related differences in the endogenous analgesic response to repeated cold water immersion in human volunteers. Pain (2000) 89:89-96. doi:10.1016/S0304-3959(00)00352-3

40. Edwards RR, Fillingim RB, Ness TJ. Age-related differences in endogenous pain modulation: a comparison of diffuse noxious inhibitory controls in healthy older and younger adults. Pain (2003) 101:155-65. doi:10.1016/S0304-3959(02) 00324-X

41. Edwards RR, Fillingim RB. Effects of age on temporal summation and habituation of thermal pain: clinical relevance in healthy older and younger adults. J Pain (2001) 2:307-17. doi:10.1054/jpai.2001.25525

42. Arendt-Nielsen L. Induction and assessment of experimental pain from human skin, muscle, and viscera. In: Jensen TS, Turner JA, Wiesenfeld-Hallin Z, editors.
Proceedings of the 8th World Congress on Pain. IASP Press (Progress in Pain Research and Management; No. 8) (1997). p. 393-425.

43. Vierck CJ Jr, Cannon RL, Fry G, Maixner W, Whitsel BL. Characteristics of temporal summation of second pain sensations elicited by brief contact of glabrous skin by a preheated thermode. J Neurophysiol (1997) 78:992-1002.

44. Averill PM, Novy DM, Nelson DV, Berry LA. Correlates of depression in chronic pain patients: a comprehensive examination. Pain (1996) 65:93-100. doi:10.1016/0304-3959(95)00163-8

45. Von Korff M, Simon G. The relationship between pain and depression. Br J Psychiatry (1996) 30:101-8.

46. Turk DC, Okifuji A. Psychological factors in chronic pain: evolution and revolution. J Consult Clin Psychol (2002) 70:678-90. doi:10.1037/0022-006X.70.3.678

47. McWilliams LA, Cox BJ, Enns MW. Mood and anxiety disorders associated with chronic pain: an examination in a nationally representative sample. Pain (2003) 106:127-33. doi:10.1016/S0304-3959(03)00301-4

48. Browne AL, Andrews R, Schug SA, Wood F. Persistent pain outcomes and patient satisfaction with pain management after burn injury. Clin J Pain (2011) 27:136-45. doi:10.1097/AJP.0b013e3181f7f9bb

49. Berna C, Leknes S, Holmes EA, Edwards RR, Goodwin GM, Tracey I. Induction of depressed mood disrupts emotion regulation neurocircuitry and enhances pain unpleasantness. Biol Psychiatry (2010) 67:1083-90. doi:10.1016/j.biopsych. 2010.01.014

50. Wiechman Askay S, Patterson DR. What are the psychiatric sequelae of burn pain? Curr Pain Headache Rep (2008) 12:94-7. doi:10.1007/s11916-008-0018-1

Conflict of Interest Statement: The authors declare that the research was conducted in the absence of any commercial or financial relationships that could be construed as a potential conflict of interest.

Received: 26 March 2014; accepted: 19 May 2014; published online: 02 June 2014 Citation: Egyhazi R, Fregni F, Bravo GL, Trinh N-HT, Ryan CM and Schneider JC (2014) Chronic pain following physical and emotional trauma: The Station nightclub fire. Front. Neurol. 5:86. doi: 10.3389/fneur.2014.00086

This article was submitted to Neurotrauma, a section of the journal Frontiers in Neurology.

Copyright (c) 2014 Egyhazi, Fregni, Bravo, Trinh, Ryan and Schneider. This is an openaccess article distributed under the terms of the Creative Commons Attribution License (CC BY). The use, distribution or reproduction in other forums is permitted, provided the original author(s) or licensor are credited and that the original publication in this journal is cited, in accordance with accepted academic practice. No use, distribution or reproduction is permitted which does not comply with these terms. 